\title{
A hybrid TEG/evacuated tube solar collectors for electric power generation and space heating
}

\author{
Hamza Al-Tahaineh *iD and Abdullah H. M. AlEssa
}

\author{
* Correspondence: h-tahaineh@bau. \\ edu.jo \\ Department of Mechanical \\ Engineering, Al Huson University \\ College, Al Balqa Applied University, \\ Irbid, Jordan
}

\begin{abstract}
The present work aimed to examine the performance of a thermoelectric generator (TEG) augmented with a hydronic evacuated tube solar collector heat exchanger used to heat a cold zone. TEGs were operated on the temperature difference between hot water circulated through the heat exchanger and the cold temperature of the surrounding space. The setup model of a heat exchanger with TEGs installed on the outer surface was examined numerically under steady state conditions for natural and forced convection modes. The results obtained show that $1.03 \mathrm{~W}$ of electricity could be produced when the temperature differences across the TEG and air velocity are $60{ }^{\circ} \mathrm{C}$ and $0.5 \mathrm{~m} / \mathrm{s}$, respectively. Also, an increase of $17.47 \%$ of TEG power was achieved for each $5^{\circ} \mathrm{C}$ drop in surrounding space temperature and by $11 \%$ for each $5^{\circ} \mathrm{C}$ rise in circulated hot water temperature. Besides the importance of improving TEG efficiencies, the amount of generated electricity may be valuable when large-surface area heat exchanger units are installed in large systems.
\end{abstract}

Keywords: Thermoelectric generator (TEG), Solar heat exchanger, Electrical energy

\section{Introduction}

Electrical energy is the most fascinating form of energy resulting from the flow of electric charge and can be used easily in various applications and needs, especially for residential, commercial, and industrial applications [1]. Electrical energy can be produced from various sources, either renewable or non-renewable. The main problem facing energy in general is the storage of energy. Heating consumes approximately one-third of the electrical energy used in residential applications [2].

Thermoelectric generators (TEGs) are thought of as direct, small solid-state energy conversion devices that can be used to directly convert waste heat into electricity as a heat recovery system [3]. The Seebeck effect is the basis of the electricity generated from the TEGs. When a heat flux passes through a junction of two completely different conductors or semiconductors, an electrical current will be generated. The Seebeck coefficient is defined as the voltage generated per $1 \mathrm{~K}$ difference in temperature [4]. Ignoring the hydraulics-thermal behavior associated, one-dimensional heat conduction

(c) The Author(s). 2022 Open Access This article is licensed under a Creative Commons Attribution 4.0 International License, which permits use, sharing, adaptation, distribution and reproduction in any medium or format, as long as you give appropriate credit to the original author(s) and the source, provide a link to the Creative Commons licence, and indicate if changes were made. The images or other third party material in this article are included in the article's Creative Commons licence, unless indicated otherwise in a credit line to the material. If material is not included in the article's Creative Commons licence and your intended use is not permitted by statutory regulation or exceeds the permitted use, you will need to obtain permission directly from the copyright holder. To view a copy of this licence, visit http://creativecommons.org/licenses/by/4.0/. The Creative Commons Public Domain Dedication waiver (http://creativecommons.org/publicdomain/zero/1.0/) applies to the data made available in this article, unless otherwise stated in a credit line to the data. 
theory is used to analyze the performance of TEGs when installed on a heat exchanger, especially in solar cell/module applications [5].

HVAC is the operation of adding or eliminating heat to obtain a more comfortable environment, and this could be achieved by using "air conditioners" through negative cooling or ventilation cooling technologies that provide heating, ventilation, and air conditioning (HVAC) [6]. In 2018, it was found that $20 \%$ of rated energy use in buildings was consumed by air conditioners, and the value was estimated to increase by three times by 2050. To that end, the United Nations encourages the development of new modified sustainable heating and cooling strategies and technologies to address global climatic changes and increased energy demand [7].

There is a wide range of equipment that could be used in thermal processes and systems where heat is dissipated into the environment as waste energy. In such devices, like heat exchangers, etc., TEGs may be installed to recover the waste energy and convert it into electricity, improving the efficiency of the thermal systems [8]. Air and water heating or cooling systems are the types that will be used to decrease or eliminate environmental impacts and can be used instead of one-time heating or cooling systems to reduce water usage or thermal water pollution [9].

Using renewable energy has become of great interest in thermal system applications, especially in heating, cooling, and power generation. But these technologies suffer from specific disadvantages related to the thermal efficiency or coefficient of performance of the system due to heat lost from the system during operation. To overcome these problems and to improve their performance, energy recovery technologies like TEGs are an excellent choice [10].

A hybrid photovoltaic-thermal water heating system was developed by Chow et al. for domestic applications. The thermal efficiency of the hybrid system was found to be in the range of $37.6-48.65 \%$ while the electrical efficiency was in the range of 10.3$12.3 \%[11,12]$.

To improve the thermal efficiency of the solar system, a new design system that combines the traditional solar cell made of silicon with TEGs and a heat collector was developed. The integrated system shows a good improvement in efficiency compared to the PV system alone [13]. For mini and micro power applications, a solar TEG was proposed by using inexpensive solar concentrators like evacuated tube collectors and parabolic or compound parabolic solar concentrators. The incorporated system was studied and showed a noticeable improvement in performance [14-17].

Recently, because of their flexibility, reliability, small size and weight, and modular scalability, TEGs are being used in a wide range of applications as heat recovery systems. In sensors as low-power supply applications $[18,19]$, medium-power supply systems include batteries [20], automotive heat systems [21, 22], stoves [23, 24], chiller systems [25], and combined TPV [26] or PV [27] systems. In heavy industries [28], geothermal systems $[29,30]$ serve as high-power supply applications.

The electric current, voltage, and hence power generated by the TEG depend mainly on the temperature difference across the TEG. The system is considered as a thermally steady-state model with a voltage source integrated in series with an internal resistance [31,32]. To enhance the generated power by the TEG for a constant temperature difference across it, the TEG load's impedance should be equal to its internal resistance [33]. 
This article provides a study of the thermal and electrical performance of a TEG system augmented with an evacuated tube solar water heater using a radiator heat exchanger by means of an Engineering Equation Solver (EES). Additionally, the effects of thermal and electrical contacts as well as free and forced convective heat transfer were considered. To characterize the TEG module's overall performance, outcomes are presented in figures for numerous essential variables, consisting of temperature, power generated, and TEG efficiencies. The variation of the heat dissipated from the heat exchanger with hot water temperatures is shown with and without installing TEGs.

\section{Method}

With the evacuated tube solar heating system, 50 TEG modules were installed around the heat exchanger, the main heat supply for space heating. As shown in Fig. 1, the hot side of the TEG is contacted perfectly on the outer surface of the heat exchanger while the cold one is in direct contact with the surrounding space air to be heated.

When the hot water from the solar collector flows through the heat exchanger, conduction heat transfers to the hot side of the TEGs, and the heat will be rejected from the cold side into the room space air as a supply heating source. As shown in Fig. 2, heat is convected from the water to the inside surface of the heat exchanger, then conducted through its wall and within the TEGs before being rejected out to the space air to be warmed. The hot and cold sides of the hybrid system are presented in Fig. 3.

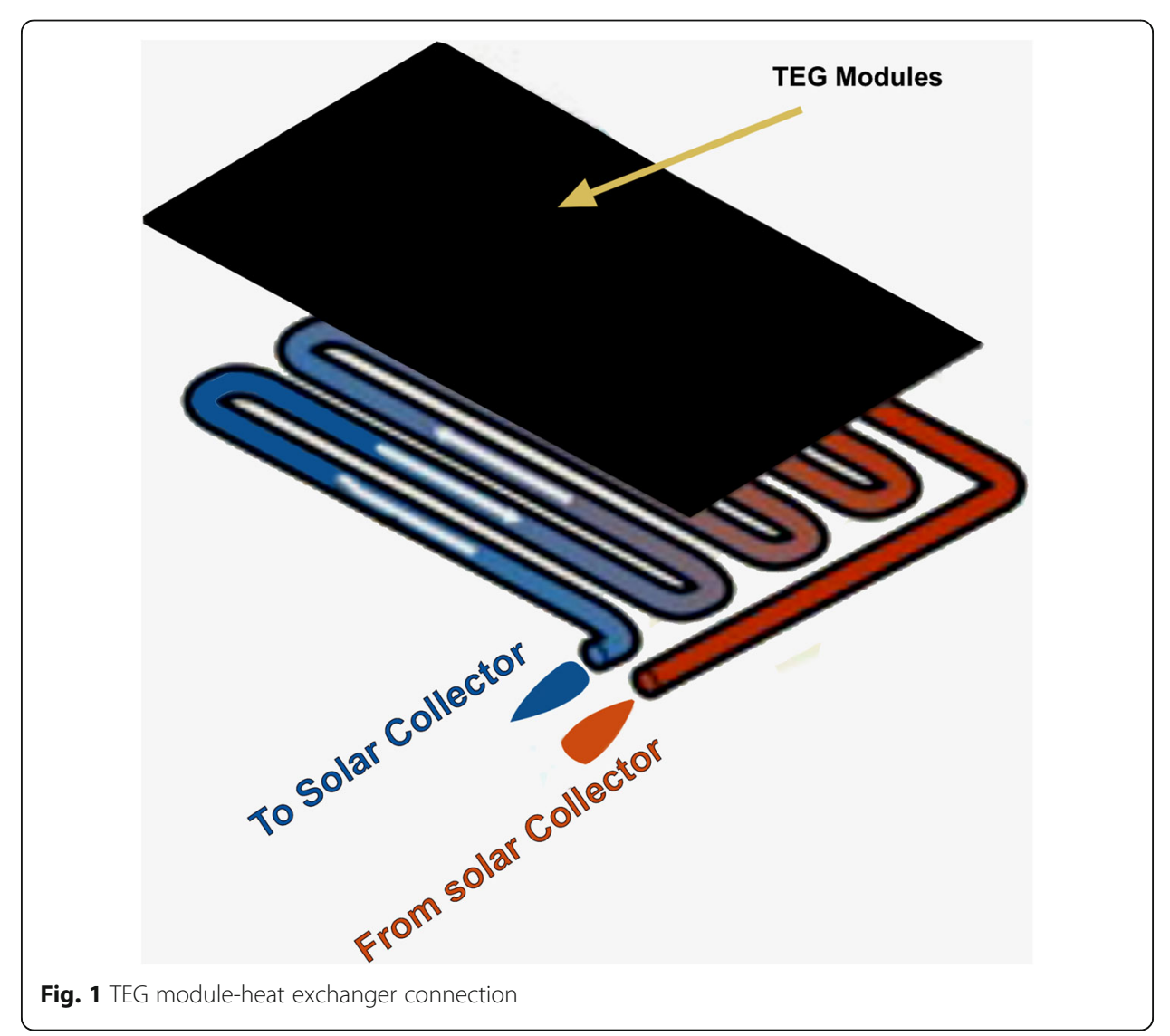




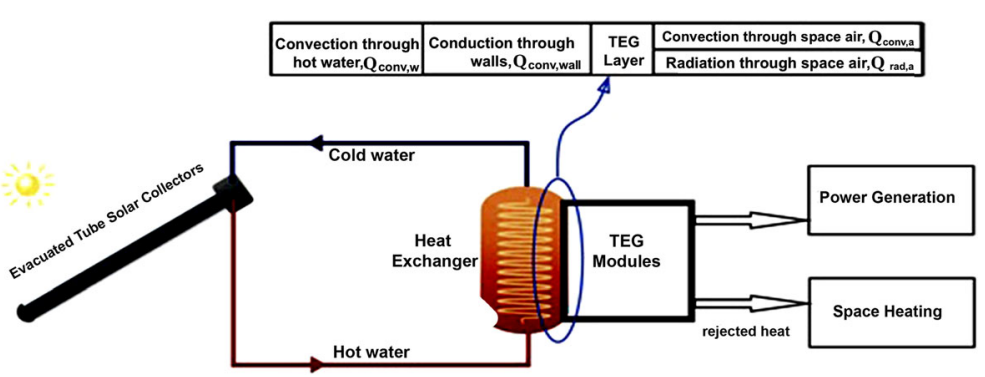

Fig. 2 Solar heat exchanger for space heating hybridized with TEG modules

It is well known that TEG is composed of p-type (positive charge) and n-type (negative charge) composites connected by a conductor. Since there is a temperature difference between the two sides of the TEG surfaces, electrical energy will be generated depending on the value of the temperature difference as shown in Fig. 4. The main variables that the amount of energy generated by the TEG will be affected by are the hot water temperature and circulation ratio, the space room temperature surrounding the TEG, and the space air speed when force convection occurs using fans. For the TEG to operate properly, there should be some differences in the physical properties (electrical resistance, thermal conductivity, Seebeck effect) of the two semiconducting pellets. The main specifications of the heat exchanger and the input parameters of the TEG modules are summarized in Tables 1 and 2, respectively.

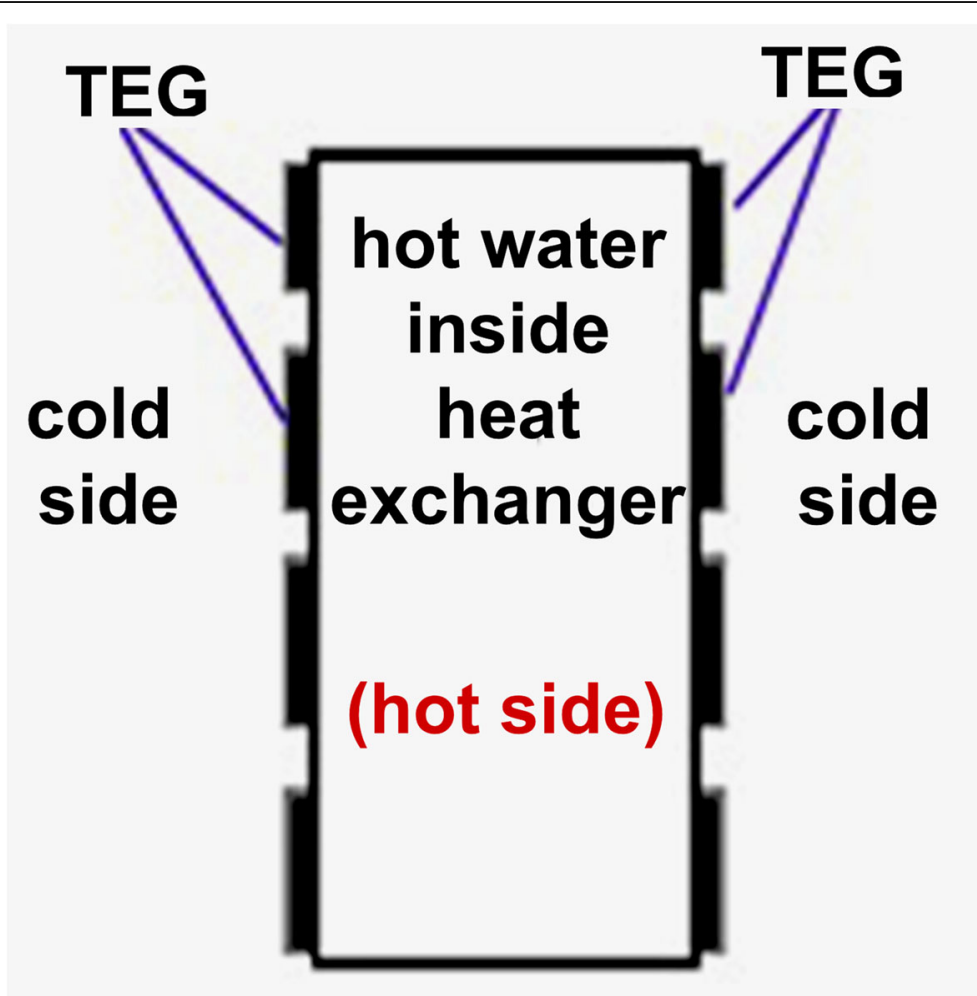

Fig. 3 Hot and cold sides of the hybrid system 

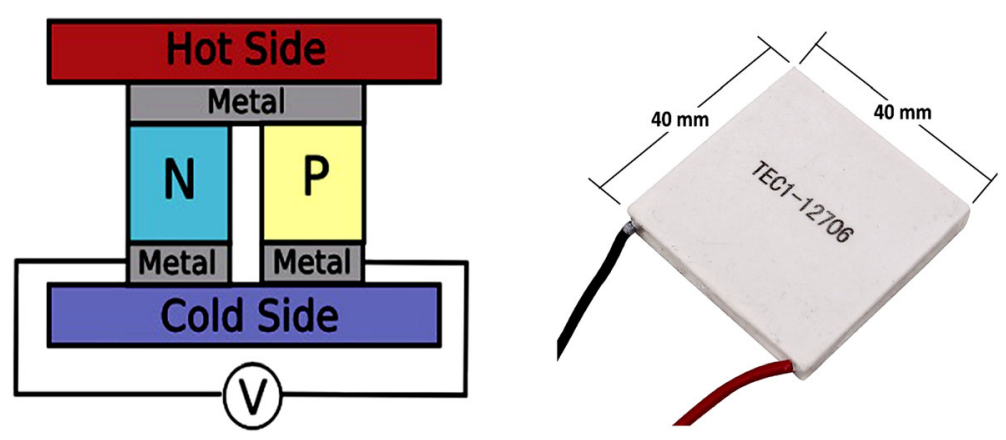

Fig. 4 Thermoelectric $\mathrm{P} / \mathrm{N}$ module

\section{Mathematical model and energy balance}

The mathematical model of the hybrid system under investigation was made based on several assumptions which can be summarized as follows:

- Steady-state, one-dimensional heat transfer.

- The outer surface area of the heat exchanger is a uniform temperature.

- Thermal and contact resistance are negligible.

- Neglecting the effect of temperature on TEG properties,

- Thermal and electrical contact resistances are negligible.

- TEG connections are considered in series thermally and in parallel electrically.

The energy balance for the heat exchanger with TEG module shown in Fig. 5 is given by Eq. (1). Note that the energy generated is negligible.

$$
\dot{E}_{1, \text { in }}-\dot{E}_{1, \text { out }}=0
$$

where $\dot{E}_{1, \text { in }}, \dot{E}_{1, \text { out }}$ are the rate of energy in and out of the between hot water and TEG module, respectively.

The rate of energy in $\dot{E}_{1, i n}$ is the rate of heat transfer from the hot water $\left(\mathrm{Q}_{\mathrm{h}}\right)$ into the TEG while the hot side heat absorption is the rate of energy out $\left(Q_{h, T E G}\right)$. Solar heated

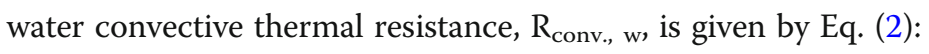

Table 1 Heat exchanger specifications

\begin{tabular}{ll}
\hline Parameter & Value \\
Height & $1(\mathrm{~m})$ \\
Width & $1(\mathrm{~m})$ \\
Wall thickness & $5(\mathrm{~mm})$ \\
Number of TEGs used on surface area & 300 \\
Material & Aluminum \\
Working fluid & Water \\
Water temperature (heated using evacuated tube solar collector) & $50-60-70-80\left({ }^{\circ} \mathrm{C}\right)$ \\
Water flow rate & $0.005-0.007-0.01-0.0159\left(\mathrm{~m}^{3} / \mathrm{s}\right)$
\end{tabular}


Table 2 TEG module input parameters at standard conditions [1]

\begin{tabular}{lll}
\hline Parameter & Value & \\
Module dimensions & $(40 \times 40)(\mathrm{mm})$ & \\
Leg cross sectional area & $(0.001 \times 0.001)(\mathrm{m})$ & \\
Leg's length & $0.0015(\mathrm{~m})$ & $223.2\left(\mu \mathrm{VK}^{-1}\right)$ \\
Seebeck coefficient & p-type & $-187.7\left(\mu \mathrm{VK}^{-1}\right)$ \\
& n-type & $0.183(\mu \mathrm{V} . \mathrm{m})$ \\
Electrical resistivity & p-type & $0.153(\mu \mathrm{V} . \mathrm{m})$ \\
& n-type & $1.68(\mathrm{~W} / \mathrm{m} \mathrm{K})$ \\
Thermal conductivity & p-type & $1.64(\mathrm{~W} / \mathrm{m} \mathrm{K})$ \\
\hline & n-type & \\
$R_{\text {conc }, w}=1 / h_{w} \cdot A_{\text {TEG }}$ & & $(2)$
\end{tabular}

where $h_{w}$ is coefficient of convective heat transfer of water $\left(\mathrm{W} \mathrm{m}{ }^{-2} \mathrm{~K}^{-1}\right)$ which can be given by ref. [34] as:

$$
h_{w}=N u_{w} \cdot \frac{K_{w}}{D_{H}}
$$

where $K_{\mathrm{w}}$ is the hot water thermal conductivity $\left(\mathrm{W} \mathrm{m}{ }^{-1} \mathrm{~K}^{-1}\right)$ and $D_{H}$ represent the hydraulic diameter of the heat exchanger which can be defined in terms of crosssectional area, $A_{c}$, and wetted perimeter of the heat exchanger as:

$$
D_{h}=4 \frac{A_{c}}{P_{w}}
$$

where $A_{c}$ is the multiplication of the width by height of the heat exchanger $\left(A_{c}=\right.$ $\left.W_{e x} \times h_{e x}\right) . N u_{w}$ is the Nusselt number of the water which can be given in terms of Reynold's number $\left(\operatorname{Re}_{w}\right)$ and Prandtl number $\left(\operatorname{Pr}_{w}\right)$ of the water as [35]

$$
N u_{w}=0.023 * \operatorname{Re}_{w}^{\left(\frac{4}{5}\right)} * \operatorname{Pr}_{w}^{0.3}
$$

In terms of water velocity, $V_{w}(\mathrm{~m} / \mathrm{s})$; density, $\rho_{\mathrm{w}}\left(\mathrm{kg} \mathrm{m}^{-3}\right)$; and dynamic viscosity, $\mu_{\mathrm{w}}$ $\left(\mathrm{N} \mathrm{m}^{-2} \mathrm{~s}^{-1}\right)$, Reynold's number of the water could be given by:

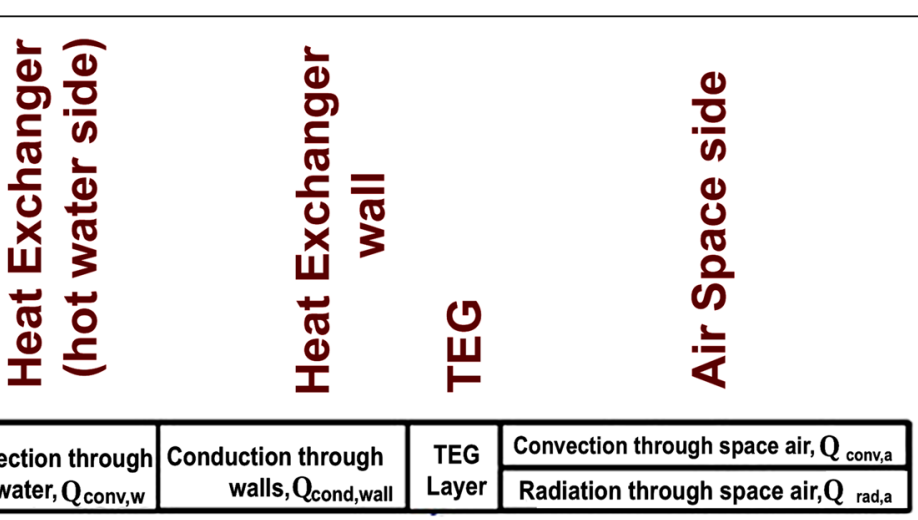

Fig. 5 Heat exchanger with TEG module 


$$
R e_{w}=\rho_{w} * V_{w} * \frac{D_{h}}{\mu_{w}}
$$

Also, Prandtl number of the water could be given by:

$$
\operatorname{Pr}_{w}=\frac{\mu_{w} \cdot C p_{w}}{K_{w}}
$$

The conduction resistance between heat exchanger surface wall and the internal surface of TEG [R cond $(K / W)]$ may be given in terms of heat exchanger thickness, $t(m)$, heat exchanger thermal conductivity, $\mathrm{K}\left(\mathrm{W} \mathrm{m}^{-1} \mathrm{~K}^{-1}\right)$, and TEG area, $\mathrm{A}_{\mathrm{TEG}}\left(\mathrm{m}^{2}\right)$ by [34].

$$
R_{\text {cond }}=\frac{t}{K * A_{T E G}}
$$

Following Eqs. (1) to (8), the rate of heat flux to the TEG from the hot water could be evaluated in terms of hot water temperature, $T_{w}$, and TEG hot side temperature, $T_{h}$, as

$$
Q_{h}=\frac{\left(T_{w}-T_{h}\right)}{R_{c o n v, w}+R_{c o n d, w}}
$$

Similarly, the energy balance equation is applied between the TEG module and the surrounding air with neglecting energy generation (see Fig. 5):

$$
\dot{E}_{2, \text { in }}-\dot{E}_{2, o u t}=0
$$

$\dot{E}_{2, \text { in }}, \dot{E}_{2, \text { out }}$ are, respectively, the rate of energy in and out between TEG module and surrounding air to be heated.

Heat transferred to the surrounding air $\left(\mathrm{Q}_{c}\right)$ occurs in combined convection and radiation modes (see Fig. 2). Thus, convective (natural and forced) and radiative heat transfer coefficients $\left[\mathrm{h}_{c, a}, h_{r, a}(\mathrm{~W} / \mathrm{m} \mathrm{K})\right]$ between the TEG module and the surrounding air are the most effective. According to Ref. [34], the air convective heat transfer coefficient $\left(\mathrm{h}_{\mathrm{c}, \mathrm{a}}\right)$ could be expressed in terms of Nusselt number $\left(\mathrm{Nu}_{\mathrm{a}}\right)$ as:

$$
h_{c, a}=N u_{a} \cdot \frac{K_{a}}{L_{r}}
$$

The Nusselt number is related to the Rayleigh number of air (Ra) as $N u_{a}=R a^{1 / 3}$ and Rayleigh number of air is well known in heat transfer and given in terms of volumetric thermal expansion coefficient of air $\beta_{\mathrm{a}}\left(\mathrm{K}^{-1}\right)$ and thermal diffusivity of air $\alpha_{\mathrm{a}}\left(\mathrm{m}^{2} / \mathrm{s}\right)$ by:

$$
R a=\frac{g * \beta_{a} * \rho_{a} *\left(T_{c}-T_{a}\right) * l_{r}^{3}}{\alpha_{a} * \mu_{a}}
$$

The volumetric thermal expansion coefficient of air is a function of the average value of water and the surrounding air temperatures $T_{f}(K)$ while the value of thermal diffusivity of air $\alpha_{\mathrm{a}}$ depends on the thermal conductivity of air $\mathrm{Ka}(\mathrm{W} / \mathrm{m} \mathrm{K})$, air density $\rho_{\mathrm{a}}$ $\left(\mathrm{Kg} / \mathrm{m}^{3}\right)$, and the specific heat of air $C p_{a}(\mathrm{~kJ} / \mathrm{kg} . \mathrm{K})$

$$
\alpha_{a}=\frac{K_{a}}{\rho_{a} * C p_{a}}
$$

The heat dissipated from the TEG to the surroundings by radiation with a normalized coefficient $h_{\mathrm{r}, \mathrm{a}}(\mathrm{W} / \mathrm{m} \mathrm{K})$ which can be written in terms of TEG emissivity $\varepsilon_{\mathrm{TEG}}$, 
Stephan Boltzmann constant $\sigma\left(\mathrm{W} \mathrm{m}^{-2} \mathrm{~K}^{-4}\right)$, and surrounding air temperature $\mathrm{T}_{\text {surr. }}$. (K) as:

$$
h_{r, a}=\varepsilon_{T E G} * \sigma *\left(T_{c}+T_{\text {surr }}\right) *\left(T_{c}^{2}+T_{\text {surr }}^{2}\right)
$$

Now, the rate of heat transfer from the cold side of the TEG $\left(\mathrm{Q}_{c}\right)$ to the ambient air can be given as:

$$
Q_{c}=h_{a} * A_{T E G} *\left(T_{c}-T_{a}\right)
$$

Respectively, the electric and thermal resistances $\left[\operatorname{Re}(\mathrm{Ohm}), \mathrm{R}_{\mathrm{th}}(\mathrm{K} / \mathrm{W})\right]$ and thermal conductivity $(\mathrm{K})$ of each TEG module are given in terms of positive and negative electric conductivity $\left(\sigma_{\mathrm{p}}=1 / \rho_{\mathrm{p}}, \sigma_{\mathrm{n}}=1 / \rho_{\mathrm{n}}\right)$ as:

$$
\begin{aligned}
& R=n \cdot\left[\left(\sigma_{p} \cdot \frac{A_{p}}{L_{p}}\right)^{-1}+\left(\sigma_{N} \cdot \frac{A_{N}}{L_{N}}\right)^{-1}\right] \\
& K=n \cdot\left[\left(\lambda_{p} \cdot \frac{A_{p}}{L_{p}}\right)+\left(\lambda_{N} \cdot \frac{A_{N}}{L_{N}}\right)\right]
\end{aligned}
$$

The rate of heat absorbed by the TEG's hot side from solar heated water $\left(\mathrm{Q}_{\mathrm{h}}\right)$ and the rate of heat rejected to the surrounding air by the TEG's cold side $\left(\mathrm{Q}_{c}\right)$ are given by:

$$
\begin{aligned}
& Q_{h}=n \cdot \bar{\alpha} T_{c} \cdot I+K \cdot\left(T_{h}-T_{c}\right)-\frac{1}{2} I^{2} R \\
& Q_{c}=n \cdot \bar{\alpha} T_{c} \cdot I+K \cdot\left(T_{h}-T_{c}\right)-\frac{1}{2} I^{2} R
\end{aligned}
$$

The power produced by TEG:

$$
P=I^{2} R_{l}
$$

The power generated by the TEG is considered as the difference between the hot and cold heat transfer rates and is given by:

$$
P=Q_{h}-Q_{c}
$$

Manipulating Eqs. (9) through (21) provides two non-linear equations with $\mathrm{T}_{\mathrm{h}}$ and $\mathrm{T}_{\mathrm{c}}$ as unknowns. EES was used to solve these equations and the results are presented.

Finally, the overall efficiency of the thermo-electric module (TEM) can be given as:

$$
\eta=\frac{P}{Q_{h}} * 100 \%
$$

Heat exchanger specifications and TEG module input parameters used in this study are presented in Tables 1 and 2, respectively.

\section{Results and discussion}

Figure 6 shows the effect of the surrounding temperature on the TEG generated power for different temperatures of hot water flowing in the heat exchanger from the solar field. The heat transfer to the surrounding air by natural convection and the temperature inversely affect the generated power. The explanation for this behavior is 


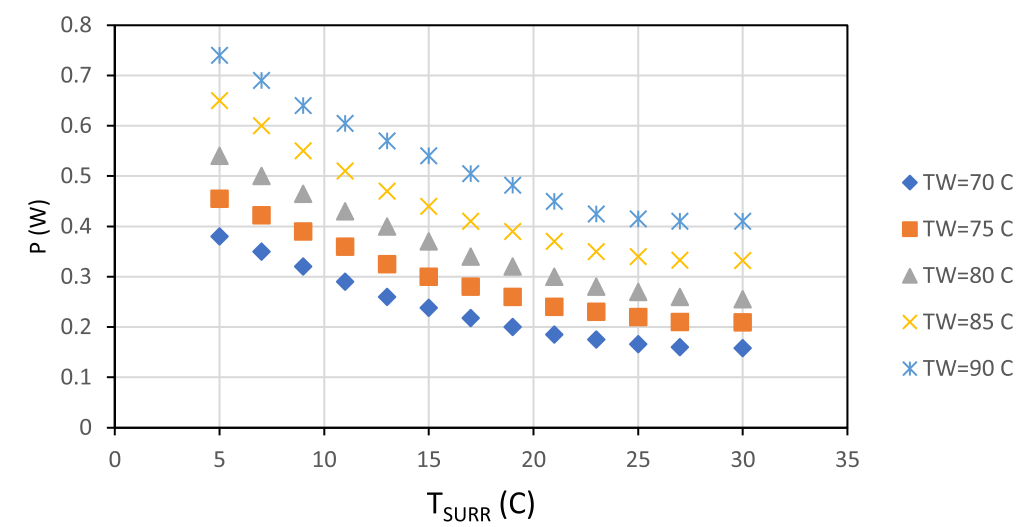

Fig. 6 Variation of power produced from TEGs with surrounding air temperature for different hot water temperatures and fixed hot water flow rate of $3 \mathrm{~kg} / \mathrm{s}$

that any increase in the surrounding temperature will cause a decrease in the temperature difference and hence decrease the heat flux across the TEG.

Increasing the velocity of the hot water shows an increase in the power generated by the TEG since any increase in the velocity will enhance the heat absorption by the hot side of the TEGs due to the increase in convective heat transfer coefficient of water with velocity, and this is clearly shown in Fig. 7. The figure also shows a slight effect of hot water velocity on power generated as compared to the surrounding temperature effect because the flow velocity values were low, hence the low Reynolds number and a slight increase in the hot water heat transfer coefficient.

It is clearly obvious that the amount of electrical power generated is small in value due to the low TEG efficiencies. Despite the low TEG efficiencies, it may be possible to generate reasonable amounts of power by increasing the heat exchanger surface area and the number of TEG modules used, especially when large amounts of waste or renewable energy are available. At least, these amounts of energy can operate wireless sensing and control devices in power plants, buildings, and so on.

Figure 8 shows the effect of hot water temperature on the power generated by the TEG for different velocities of hot water flowing in the heat exchanger from the solar field. The results presented show that the TEGs generate more power as the hot water

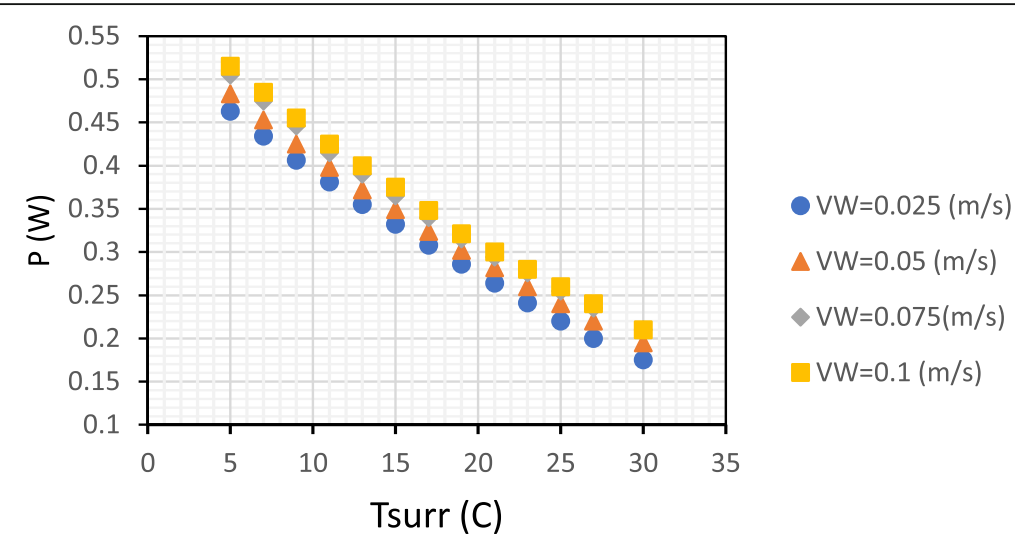

Fig. 7 Variation of power produced from TEGs with surrounding air temperature for different hot water flow velocities under the condition of natural convection at hot water temperature of $85^{\circ} \mathrm{C}$ 


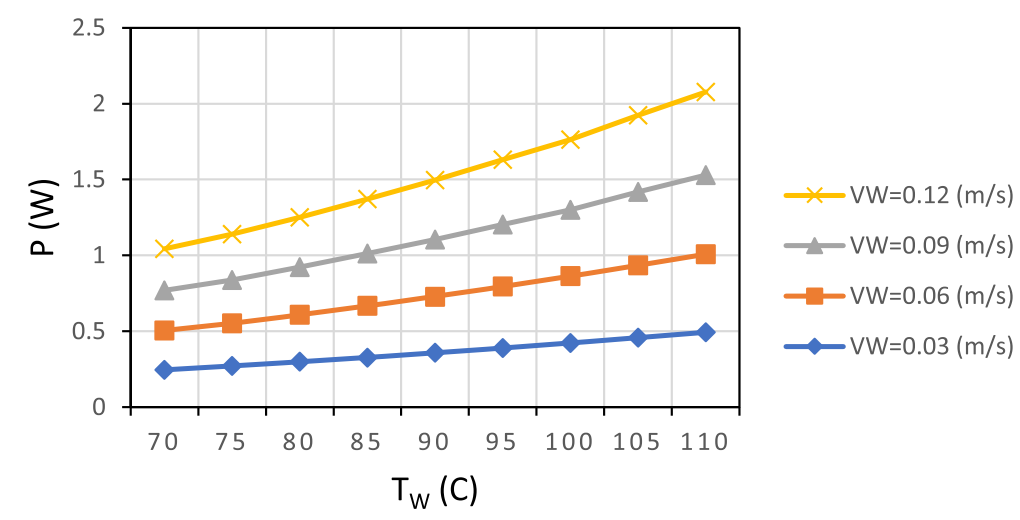

Fig. 8 Effect of hot water temperature on the TEGs' generated power for different hot water flow velocities under the condition of natural convection at a surrounding temperature of $20^{\circ} \mathrm{C}$

temperature increases due to the increase in heat flux from the hot water side and the TEG hot side, resulting in a larger temperature difference across the TEGs.

It is well known that enhancing the heat transfer will improve the electric power generated from the TEGs. Figure 9 shows that natural convection produces less power than that in the case of forced convection, and this is due to the lower heat transfer coefficient in the case of natural convection as compared to forced convection. Also, in the case of forced convection, the velocity of space air surrounding the cold side of the TEGs directly affects the rate of heat transfer and enhances the power generated. The coefficient of convective heat transfer increases with the speed of air, which causes the heat transfer exchanged through the heat exchanger. According to ISO7933, the recommended value of the moving air heat transfer coefficient was taken as $6\left(\mathrm{~W} / \mathrm{m}{ }^{\circ} \mathrm{C}\right)$ at $0.5 \mathrm{~m} / \mathrm{s}$ air speed [36]. With natural convection, the heat transfer rate will be lower.

When investigating the effect of hot water temperature on TEG efficiency for different surrounding conditions, it was found that the efficiency was found to increase with increasing hot water temperature and decreasing surrounding temperatures due to the

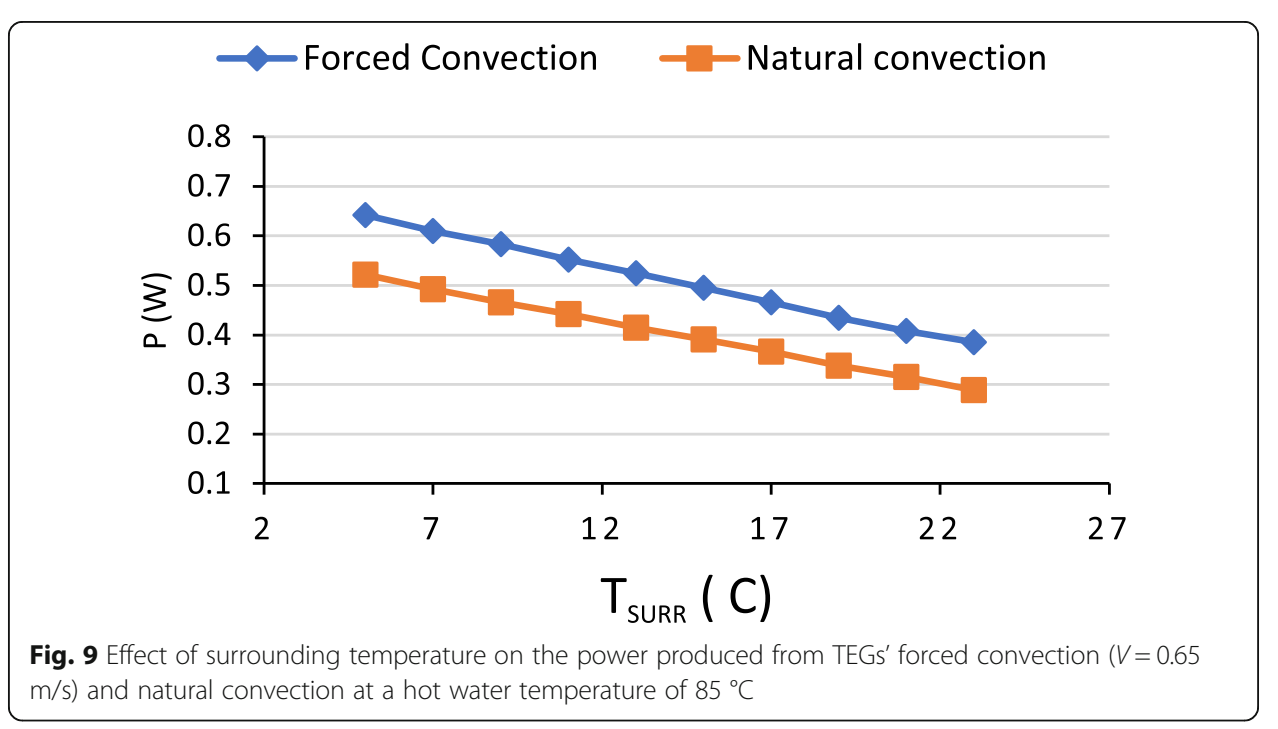




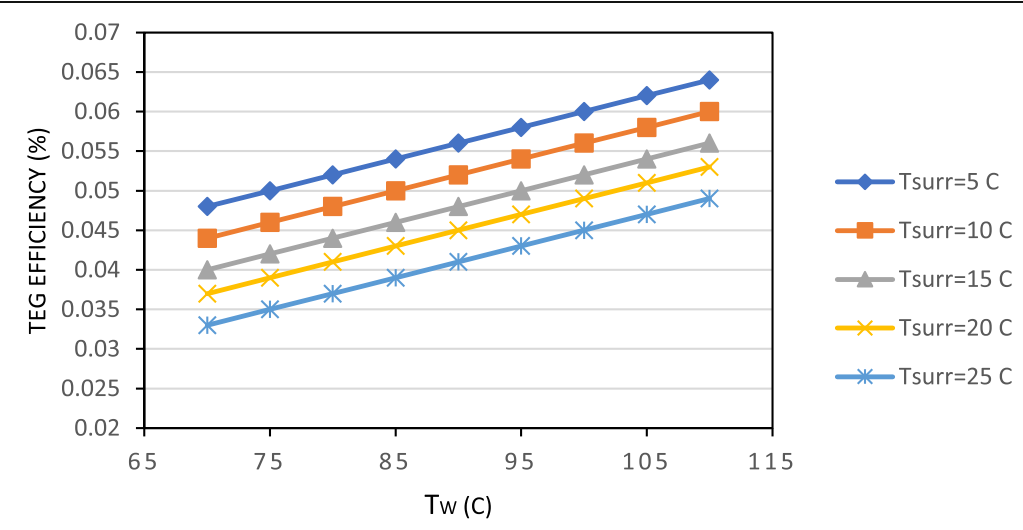

Fig. 10 Variation of TEG efficiency with hot water temperature for different surrounding temperatures

increase in temperature differences across the TEGs as mentioned earlier. The effect of combined hot water and surrounding temperatures is presented in Fig. 10.

The effect of combined surrounding temperature and hot water flow velocity on TEG efficiency is shown in Fig. 11. The results indicate that the efficiency decreases as the surrounding temperature increases due to the decrease in heat dissipated to the TEGs' cold side and, hence, decreases the temperature difference across the TEGs, which lowers the electric power generated.

Figure 12 compares the heat dissipated to the surroundings when the heat exchanger is operated with or without TEGs installed on the heat transfer surface area. The results show a negligible difference between the two cases.

\section{Model validation}

To validate the results obtained in the present investigation, a published study by AlWidyan et al. [1] was selected. Al-Widyan et al. investigate a heating radiator with TEGs installed on both sides (cold and hot). The published study's input data was applied to the current investigation model. Figures 13, 14, and 15 show the model validation by comparing the effect of the surrounding temperature on the power produced from TEGs for hot water temperatures of $345 \mathrm{~K}$ with a fixed water mass flow rate of 3 $\mathrm{kg} / \mathrm{s}$ for both models, the variation of the power produced by one TEG's module with

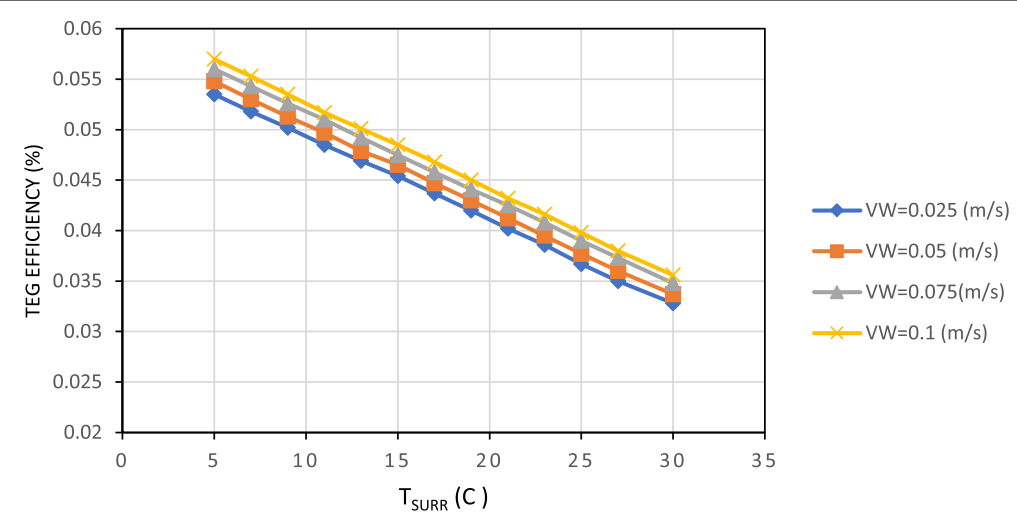

Fig. 11 Effect of the surrounding temperature on TEG efficiency for different hot water temperatures 


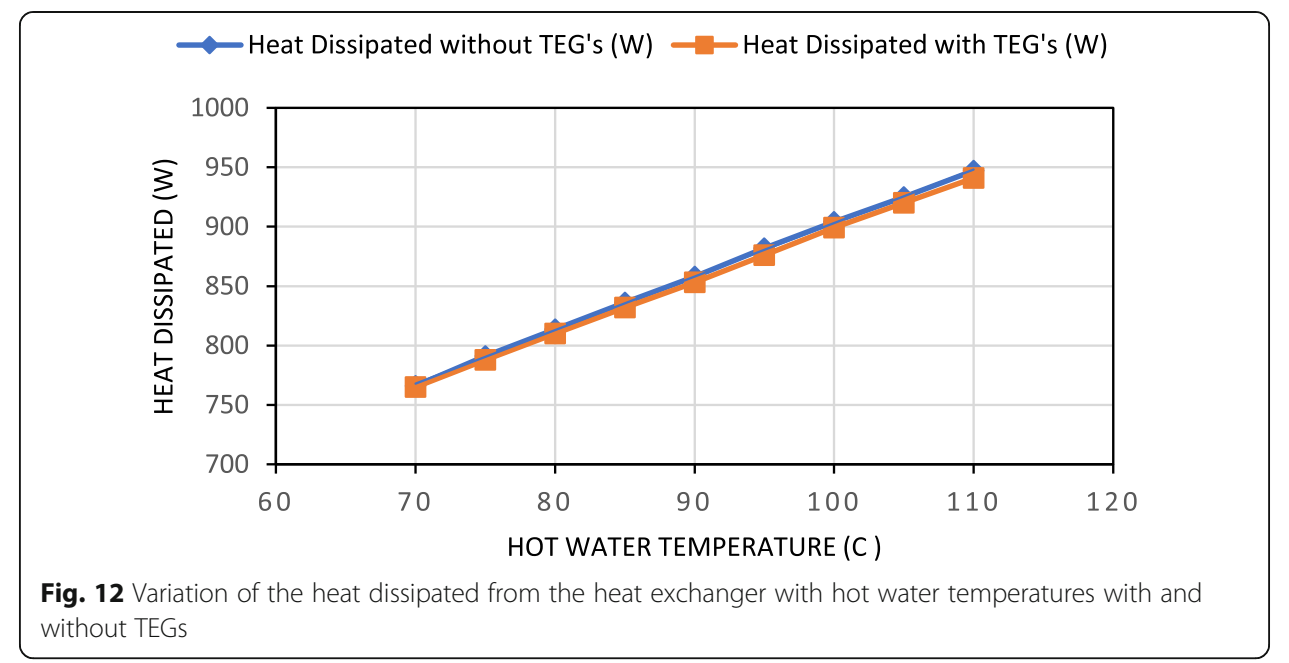

the temperature difference across the heat exchanger, and the variation of the TEG's efficiency with the temperature difference across the heat exchanger. The present model shows high agreement with the published (true) model, with an error of less than 6\%.

\section{Conclusion}

The present investigation proposes the installation of TEGs at the outer surface of the heat exchanger in which hot water is heated by an evacuated tube solar collector and flows through it to heat the surrounding space. This study may not be the first one that addresses solar space heating systems, but it is one of the first that professes the concept of augmenting TEGs for space heating systems. The results of the present work clearly indicate that such kinds of TEG applications hold a promising potential for solar and other renewable sources of energy as well as recovering waste energy.

In this study, the effect of various parameters on TEG efficiency and power generation was examined. The surrounding air temperature and the hot water temperature coming from the evacuated solar collector represent the most significant parameters affecting the performance of the TEGs. Besides heating the space, the heat exchanger with TEGs installed on the outer surface produces a

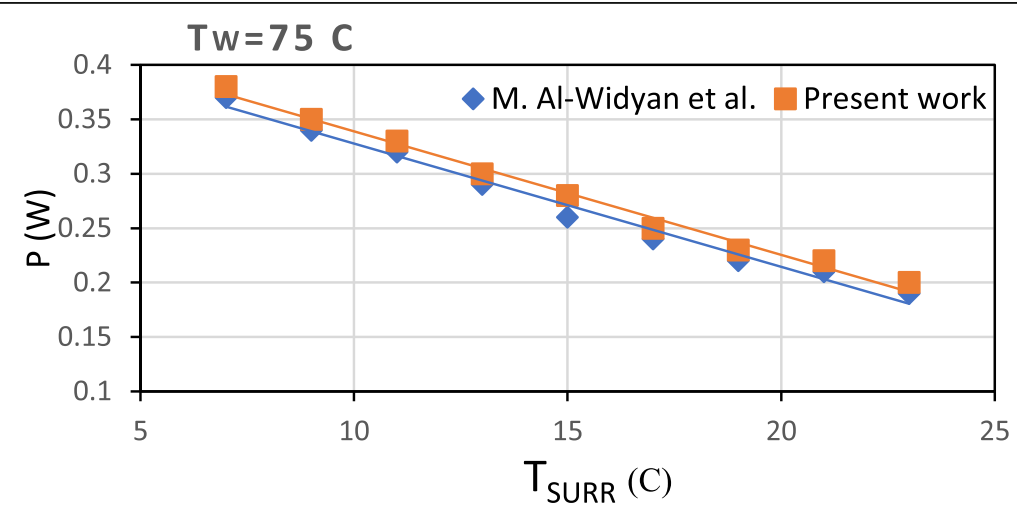

Fig. 13 Variation of power produced from TEGs with surrounding temperature for hot water temperatures of $345 \mathrm{~K}$ with fixed water flow rate of $3 \mathrm{~kg} / \mathrm{s}$ (model validation) 

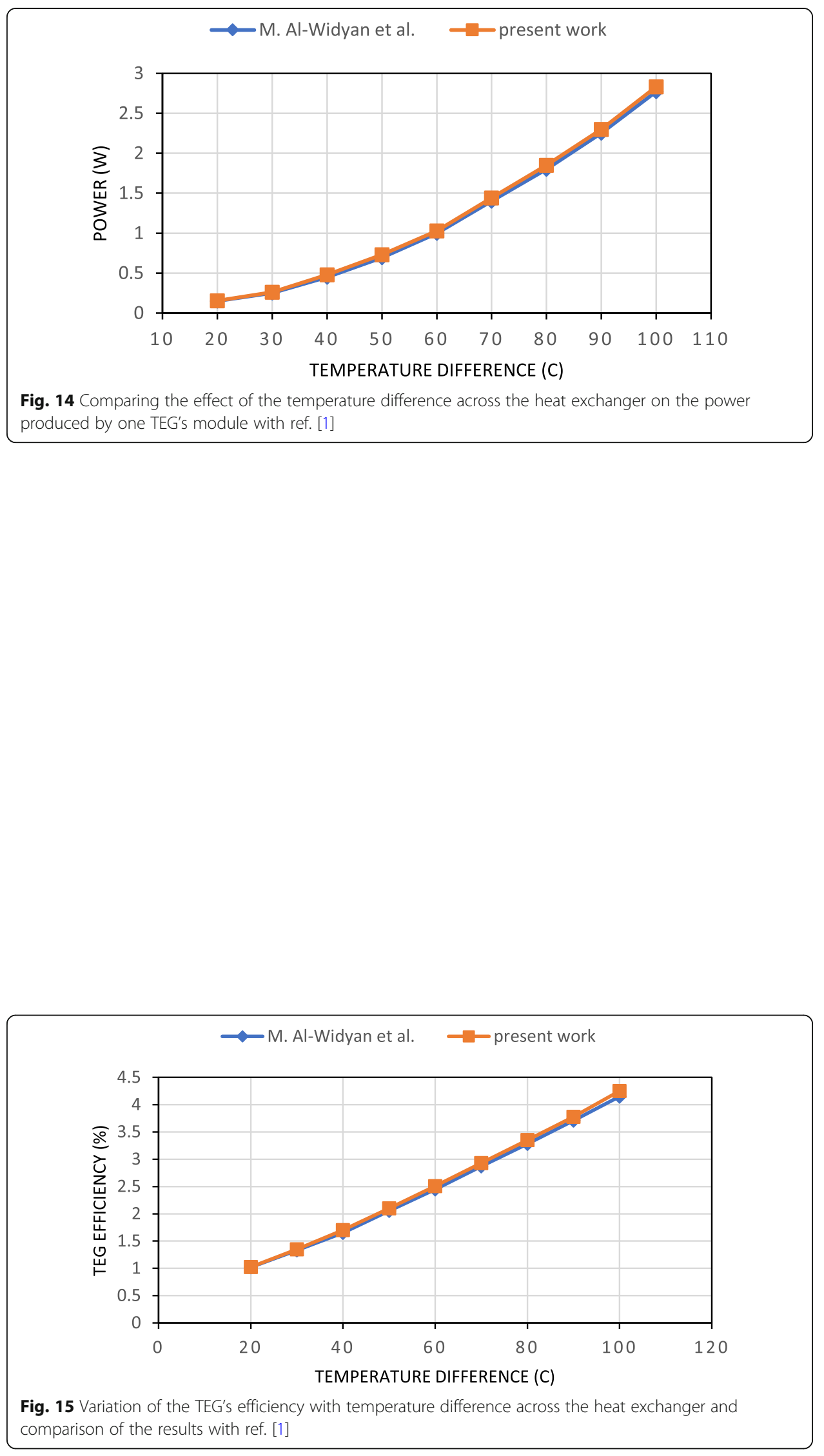
maximum electric power of $1.03 \mathrm{~W}$ at a temperature difference across the TEG of $60{ }^{\circ} \mathrm{C}$. The optimum air velocity that gives the optimum power generated was found to be $0.5 \mathrm{~m} / \mathrm{s}$. Furthermore, a decrease in the surrounding temperature by $5{ }^{\circ} \mathrm{C}$ increases the power produced by about $17.47 \%$, while it increases by about $11 \%$ as the hot water temperature increases by $5{ }^{\circ} \mathrm{C}$.

\begin{abstract}
Abbreviations
$A_{c}$ : Heat exchanger area $\left(m^{2}\right) ; A_{N}$ : Area of negative leg $\left(m^{2}\right) ; A_{p}$ : Area of positive leg $\left(m^{2}\right) ; A_{T E G}$ : Thermoelectric generator area $\left(\mathrm{m}^{2}\right)$; $C \mathrm{p}_{\mathrm{w}}$ : Water specific heat $\left(\mathrm{kJ} \mathrm{kg}^{-1} \mathrm{~K}^{-1}\right)$; $\mathrm{D}_{\mathrm{h}}$ : Hydraulic diameter of the heat exchanger $(\mathrm{m})$; E: Energy; $h_{c, a}$ : Air convective heat transfer coefficient $\left(W^{-2} K^{-1}\right) ; h_{r, a}$ : Air radiative heat transfer coefficient $\left(W m^{-2}\right.$ $\left.\mathrm{K}^{-1}\right) ; h_{\mathrm{w}}$ : Water convective heat transfer coefficient $\left(\mathrm{W} \mathrm{m}^{-2} \mathrm{~K}^{-1}\right) ; \mathrm{h}_{\mathrm{ex}}$ : Height of the heat exchanger $(\mathrm{m}) ;$ l: Electric current (amp); $K_{a}$ : Air thermal conductivity $\left(\mathrm{W} \mathrm{m}^{-1} \mathrm{~K}^{-1}\right) ; \mathrm{K}_{\mathrm{w}}$ : Hot water thermal conductivity $\left(\mathrm{W} \mathrm{m}^{-1} \mathrm{~K}^{-1}\right)$; $\mathrm{L}_{\mathrm{N}}$ : Area of negative leg (m); Lp: Area of positive leg (m); Nu: Nusselt number; P: Power; Pe: Heat exchanger perimeter (m); Pr: Prandtl number; PV: Photovoltaic; $Q_{h}$ : Rate of heat transfer from the hot water $(\mathrm{kJ}) ; \mathrm{Q}_{\mathrm{h}, \mathrm{TEG}}$ : TEG hot side heat

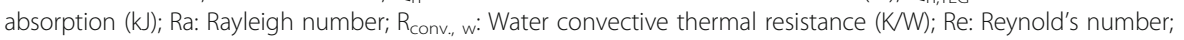
$R_{e}$ : Electric resistances $(\mathrm{Ohm}) ; R_{\text {th }}$ : Thermal resistances (KW); t: Thickness (m); TEG: Thermoelectric generator; TEM: Thermoelectric module; $T_{h}$ : TEG hot side temperature $\left({ }^{\circ} \mathrm{C}\right) ; \mathrm{T}_{\text {surr: }}$ Surrounding air temperature $\left({ }^{\circ} \mathrm{C}\right) ; \mathrm{T}_{\mathrm{w}}$ : Hot water temperature $\left({ }^{\circ} \mathrm{C}\right)$; TPV: Thermal Photovoltaic; $V_{w}$ : Water velocity $(\mathrm{m} / \mathrm{s}) ; \rho_{\mathrm{w}}$ : Water density $\left(\mathrm{kg} \mathrm{m}^{-3}\right) ; \mu_{\mathrm{w}}$ : Water dynamic viscosity $\left(\mathrm{N} \mathrm{m}^{-2} \mathrm{~s}^{-1}\right)$; $\beta_{\mathrm{a}}$ : Volumetric thermal expansion coefficient of air $\left(\mathrm{K}^{-1}\right)$; $a_{\mathrm{a}}$ : Thermal diffusivity of air $\left(\mathrm{m}^{2} / \mathrm{s}\right)$; $\varepsilon_{\text {TEG: }}$ TEG emissivity; $\sigma$ : Stephan Boltzmann constant $\left(\mathrm{W} \mathrm{m}^{-2} \mathrm{~K}^{-4}\right) ; \sigma_{\mathrm{p}}$ : Positive electric conductivity; $\rho_{\mathrm{n}}$ : Negative electric conductivity
\end{abstract}

\title{
Acknowledgements
}

Not applicable.

\section{Authors' contributions}

Hamza Al-Tahaineh: supervision, investigation, methodology, writing, reviewing, and editing. Abdullah AlEssa: software, data analysis, validation, writing, reviewing, and editing. The authors read and approved the final manuscript.

\section{Funding}

The authors declare that the present investigation was conducted by the author without any funding resources.

\section{Availability of data and materials}

Datasets supporting the findings of this study are included in the literature.

\section{Declarations}

\section{Competing interests}

The authors declare that this submission is entirely their own work, and that all sources used in researching it are fully acknowledged, and that they have no known competing financial, non-financial, or other interests that may appear to influence the present reported work.

Received: 20 September 2021 Accepted: 9 December 2021

Published online: 22 January 2022

\section{References}

1. Al-Widyan M, Al-Nimr M'd, Al-Oweiti Q (2021) A hybrid TEG/Thermal radiator system for space heating and electric power generation. J Build Eng 41:102364

2. Burgess M, Pimentel D (2018) World Human Population Problems. Encycl Anthropocene 4:313-317

3. Orr B, Akbarzadeh A (2017) Prospe cts of waste heat recovery and power generation using thermoelectric generators. Energy Procedia 110:250-255

4. Hewawasam LS, Jayasena AS, Afnan MMM, Ranasinghe RACP, Wijewardane MA (2020) Waste heat recovery from thermo-electric generators (TEGs). Energy Rep 6(Supplement 2):474-479

5. Li W, Paul MC et al (2016) Thermal performance of two heat exchangers for thermoelectric generators. Case Stud Therm Eng 8:164-175

6. Gulledge 111, charles; knight, Dennis (11 February 2016) (2021). Heating, ventilating, air-conditioning, and refrigeration engineering. Annals of R.S.C.B., ISSN:1583-6258 25(4):13134-13140

7. Mohamed Mady AA (2010) In: Lehmann HA, Wear J, Qawasmi AL (eds) Traditional ways of dealing with climate in Egypt

8. ASHRAE Technical Committee (TC) 1.6, Terminology. TC 1.6

9. Thulukkana, K, Heat exchanger design handbook, 2013. (Retrieved 3 February 2019).

10. Hug R (2009) Cooling with solar heat: growing interest in solar air conditioning. The solarserver Forum for Solar Energy, Germany

11. Chow TT, He W, Ji J (2006) Hybrid photovoltaic-thermosyphon water heating system for residential application. Sol Energy 80:298-306

12. Ji J, Lu JP, Chow TT, He W, Pei G (2007) A sensitivity study of a hybrid photovoltaic/thermal water-heating system with natural circulation. Appl Energy 84:222-237

13. Li W, Paul MC, Montecucco A, Siviter J et al (2017) Multiphysics simulations of thermoelectric generator modules with cold and hot blocks and effects of some factors. Case Stud Thermal Eng

14. Amatya R, Ram RJ (2010) Solar thermoelectric generator for micropower applications. J Electron Mater 39:1735-1740 
15. Li GQ, Pei G, Yang M, Ji J, Su YH (2014) Optical evaluation of a novel static incorporated compound parabolic concentrator with PV/thermal system and preliminary experiment. Energy Convers Manag 85:204-211

16. Liao T, Lin B, Yang Z (2014) Performance characteristics of a low concentrated photovoltaic thermoelectric hybrid power generation device. Int J Therm Sci 77:158-164

17. Lertsatitthanakorn C, Jamradloedluk MR (2013) Thermal modelling of a hybrid thermoelectric solar collector with a compound parabolic concentrator. J Electron Mater 42(7):2119-2126

18. Ramadass YK, Chandrakasan AP (2011) A battery-less thermoelectric energy harvesting interface circuit with $35 \mathrm{mV}$ startup voltage. IEEE J Solid-State Circ 46:333-341

19. Elefsiniotis A, Kokorakis N, Becker T, Schmid U (2014) A thermoelectric-based energy harvesting module with extended operational temperature range for powering autonomous wireless sensor nodes in aircraft. Sens Actuat A Phys 206:159-164

20. Kinsella C, O'Shaughnessy S, Deasy M, Duffy M, Robinson aJ. (2014) Battery charging considerations in small scale electricity generation from a thermoelectric module. Appl Energy 114:80-90

21. Crane D, LaGrandeur J, Jovovic V, Ranalli M, Adldinger M, Poliquin E et al (2012) TEG on-vehicle performance and model validation and what it means for further TEG development. J Electron Mater

22. Risse S, Zellbeck H (2013) Close-coupled exhaust gas energy recovery in a gasoline engine. Res Therm Manage 74:54-6

23. Manikandan S, Kaushik SC (2015) Thermodynamic studies, and maximum power point tracking in thermoelectric generator-thermoelectic cooler combined system. Gryogenics 67:52-62

24. O'Shaughnessy S, Deasy M, Kinsella C, Doyle J, Robinson A (2013) Small scale electricity generation from a portable biomass cookstove: prototype design and preliminary results. Appl Energy 102:374-385

25. Chen M, Lund H, La R, Condra TJ (2010) Energy efficiency analysis and impact evaluation of the application of thermoelectric power cycle to today's CHP systems. Appl Energy 87:1231-1238

26. Qiu K, Hayden ACS (2012) Development of a novel cascading TPV and TE power generation system. Appl Energy 91 : 304-308

27. Sark W (2011) Feasibility of photovoltaic thermoelectric hybrid modules. Appl Energy 88:2785-2790

28. Kaibe H, Makino K, Kajihara T, Fujimoto S, Hachiuma H (2011 (ECT'11)) Thermoelectric generating system attached to a carburizing furnace at Komatsu Ltd., Awazu Plant. In: 9th European conference on thermoelectrics, pp 524-527

29. Suter C, Jovanovic Z, Steinfeld A (2012) A 1-kWe thermoelectric stack for geothermal power generation: modeling and geometrical optimization. Appl Energy 99:379-385

30. Patyk A (2013) Thermoelectric generators for efficiency improvement of power generation by motor generators: environmental and economic perspectives. Appl Energy 102:1448-1457

31. Rowe D, Min G (1998) Evaluation of thermoelectric modules for power generation. J Power Sources 73:193-198

32. Lineykin S, Ben-Yaakov S (2007) Modeling, and analysis of thermoelectric modules. IEEE Trans Ind Appl 43:505-512

33. Laird I, Lovatt H, Savvides N, Lu D, Agelidis VG (2008) Comparative study of maximum power point tracking algorithms for thermoelectric generators. In: Australasian universities power engineering conference (AUPEC'08)

34. Bergman TL, Incropera FP, DeWittD P, Lavine AS (2011) Fundamentals of heat and mass transfer. Wiley, USA

35. Ssennoga T, Jie Z, Yuying Y, Bo L (2016) A comprehensive review of thermoelectric technology: materials, applications, modelling and performance improvement. Renew Sustain Energy Rev 65:698-726

36. International Organization for Standardization (ISO), ISO7933, Hot analytical determination and interpretation of thermal stress using calculation of required sweet rate, 2004.

\section{Publisher's Note}

Springer Nature remains neutral with regard to jurisdictional claims in published maps and institutional affiliations.

\section{Submit your manuscript to a SpringerOpen ${ }^{\circ}$ journal and benefit from:}

- Convenient online submission

- Rigorous peer review

- Open access: articles freely available online

- High visibility within the field

- Retaining the copyright to your article

Submit your next manuscript at $\boldsymbol{\sim}$ springeropen.com 